\title{
Making Magic: (Hetero)sexual (In)visibility in Scandinavian Young Adult Novels
}

\author{
Mia Franck and Rebecka Fokin-Holmberg
}

\begin{abstract}
In Scandinavia, there is a commonly held assumption that gender equality has already been accomplished. In fictional representations, however, gender and sex roles are more problematic. This study of the depiction of girlhood in Scandinavian young adult novels demonstrates socially and culturally driven constructions of gender power that are markedly conservative. The girl protagonists typically deal with conventional issues of growing up, including coming to terms with what it means to be a girl and how to relate to (hetero)sexuality. However, the complexities of this maturational process can be extrapolated when their otherness is embodied in the trope of a witch-girl.
\end{abstract}

The witch character in children's and young adult literature is a widespread, stock figure. John Stephens makes this claim specifically in relation to literature for young readers (Stephens 2003, p 195). He schematizes literary representations into three different categories of witchfigures: the wise-witch, the crone-witch and the sorceresswitch (pp.195-198). In young adult fiction, witch-girls are typically depicted as they develop and mature into their role as witches. Our intentions are to examine the positioning of witch-figures and show how authors use witchhood as a vehicle for female agency and as a subversive strategy in the depiction of girls. This article will therefore explore how the image of the witch girl is related to the concept of friendship and sexuality. In order to do this, we will focus on the ways in which representations of witchhood underscore issues of heterosexuality and lesbianism. Stephens's categories of witch-figures are, therefore, too limited to apply to our analytic strategy.

Our article will scrutinize the witch protagonist within fantastic and realistic narratives. The first part of the article presents analyses of two Swedish young adult novels by Inger Edelfeldt and Katarina Mazetti. Both Edelfeldt's (1982) novel Juliane och jag [Juliane and I] and Mazetti's (1998) Det är slut mellan Rödluvan och vargen [It is over between Red Riding Hood and the Wolf] ${ }^{1}$ represent witches within a realistic context, although the first novel, Juliane and $I$, alludes to the gothic. The second part of the article focuses on the Danish author Lene Kaaberbøl's tetralogy Skammerens datter (2000-2003) [The Shamer's chronicles 2004-2005], which places the girl witch within a fantastic setting.
The maturation motif, which is so central in young adult novels, is connected to power relations. To examine this motif we have drawn on Michel Foucault's study The History of Sexuality (1978), in which he discusses the omnipresent operation of power. For the depiction of girlhood, power struggles highlight how sexuality is constructed as it shows the tense connection between power and sexuality. Judith Butler's study Gender Trouble (1990, 1999) builds on Foucauldian ideas but applies them directly to the issues of gender and sexuality. Butler argues that through subversive and parodic repetitions sexuality is practised and made visible. Thus agency both constitutes and restricts transgressive actions (Butler 1999, p.158). In our discussion we will employ Butler's theory of performativity which is further developed in her study Bodies that matter (1993).

The key questions we raise are: What kind of sexuality can the witch girl perform within realistic and fantastic settings? Do realistic depictions and fantasy open up different understandings of sexuality? How is the girl's awareness of sexuality depicted and what potential is there to question hegemonic preconditions for sexuality? Sexuality and power are closely related and it is, therefore, essential to scrutinize whether the girl protagonists have agency over their own performativity.

\section{Friendship on the edge}

Representations of girl witches in Scandinavian young adult novels both subvert and conform to heteronormativity. This is explicitly expressed through the girls'sexual preferences or in subtexts that reveals very intimate friendship relations between the girls.

In Mazetti's novel, the main charcter, Linnea, is explicit about her sexual orientation when she thinks of a boy she was friends with. At first she thinks they are a couple, but then she discovers that they are both interested in boys:

I could have talked to him about it, but I started to avoid him instead. Not because I had any specific ideas about people who are Homosexual -I don't know enough about it. It's tricky. I mean, to them it must feel just like being heterosexual, I guess. Still, I wouldn't like it if people went around whispering about my sexuality. 
"There's Linnea, did you know she is
heterosexual?"

As if I was Sexual all the time.

(Mazetti 1998, p.35)

Linnea openly acknowledges her heterosexuality, but she is also conscious of alternative views on sexuality. Her appraisal of the situation shows that heterosexuality is constructed as a norm in this text and that sexuality is not always visible. According to Roberta Trites, young adult novels in general discuss sexuality from a range of different viewpoints (Trites 2000,p.84). The changeability of sexual norms, which mirrors both the sexual act and the question of sexual orientation, is examined through multiple perspectives. Kate McInally's discussion of Australian young adult fiction points to a normative identity framework which is based on psychosexual development. She claims that 'the accepted model of development and maturation encourages the construction of only two subject positions in the text; either the implied heterosexual character (and reader) or one based on identity politics' (McInally 2003, p.27). When novels foreground these identity politics, specific sexual identities can be emphasized and transformed when young protagonists evaluate how gender is constructed and performed. Butler argues that if 'sexuality is culturally constructed within existing power relations, then the postulation of a normative sexuality that is "before", "outside", or "beyond" power is a cultural impossibility' (Butler 1999, p.40). Young adult novels illustrate this when their young characters question sexual normativity, yet still perform within the bounds of conformity. Classmates, friends, grown-ups - they all function as regulating institutions for doing sexuality and gender.

Friendship is a central issue in the depictions of girlhood. Often the border between friendship and lesbianism is blurred. This happens in Mazetti's novel when Linnea is surprised by her friend Malin's amulet:

"Would you like to see my amulet?" [...] Then [Malin] opened the little bag with a secretive, enthusiastic smile. She poured out the contents on a little white handkerchief on her desk. There were dried flowers, a feather, a pearl button and a little silver ring.

And a picture of me.

(p.54)

Linnea is looking at the contents of Malin's amulet and though she earlier pointed out that she is aware of, and appreciates, Malin's dependency on her, she is confronted when she sees her own picture in the amulet. The picture suggests that Malin may be overestimating the intimacy of their friendship. Malin carries the picture close to her body and then actively shows it to Linnea to indicate the intensity of her feelings for her. The closeness between the girls is never a direct expression of lesbian feelings, but it does imply the possibility of same-sex desire.

Linnea tends to avoid situations that in some way interrupt her perception of normality. When something confuses her, she mentions it, but does not dwell on it. So when Malin has revealed the contents of her amulet, Linnea makes no comment. However, in the quotation above the phrase, And a picture of me, is singled out as crucial. Linnea's limited point of view as narrator reveals that she finds the whole matter both ridiculous and annoying. According to the narratologist, Maria Nikolajeva, a young character-narrator in children's literature is, by definition, naïve and unreliable, since the young person lacks experience. The limited view of young characters is often used by authors as a primary narrative device (Nikolajeva 2002, p.5). Linnea willingly discusses her opinion of sexuality, but confronted with Malin's preferences she avoids any further discussion and deals only with what is in her own interest and ability to acknowledge. She is unreliable in being apparently open to questions of sexual preference, but at the same time directly avoiding any acknowledgment of Malin's desires. Linnea accepts difference unless she has to confront it, and therefore she shuts Malin out. The closeness Malin offers her is apparently too intimidating for Linnea.

Representations of girl witches are typically characterized by a community of friendship or a female-female connection. Trites reads Little Women from a queer perspective and points out how difficult it is to define lesbianism in absolute terms. She is more interested in articulating 'the repression of female-female sexuality' and therefore suggests that 
Little Women can be read through a lesbian subtext (Trites 1999, pp.142-144). Trites shows how Jo gains strength from her relationships with Marmee and her sisters. The closeness between the women forms a sanctuary where heterosexism cannot reach them; instead they gain power within the close circle (Trites 1999, pp.144-148).

Similar motifs of close friendship verging on lesbianism are more openly addressed in Edelfeldt's Juliane and I. The closeness between Juliane and Kim constitutes a sanctuary where they can share their interest in performing as witches. Despite this, the intensity of the girls' feelings is never acted upon. Lesbianism is suggested, but the girls never dare overtly raise the subject. Kim comments on the matter as follows:

I felt a strong urge to hold her when she looked so afraid, but I didn't dare. I didn't dare to touch Juliane, I was so afraid, that if I did, it would feel strange, and something would be broken.

(Edelfeldt 1982, p.162)

Friendship is transformed by desire for physical contact, but it is not possible for the girls to act on that desire within the confines of heterosexual normality because as Kim says 'it would feel strange, and something would be broken'. Desire has to be restrained since many people in the narrative are already suspicious of Kim and Juliane's strong connection. The girls are able to talk about many things, but not this sexually-loaded taboo.

Performativity is essential for these girls. They act as witches in that they take on a specific mode of agency connected to witcheraft and this agency consists of how they perform rites and obey certain rules in accordance with specific words and 'magical' objects. Performing as witches, the girls illustrate a different kind of girlhood. The performative nature of their witchhood conforms to Butler's discussion of drag performances. Butler explains that through drag performances it is possible to show the normative function of heterosexuality. Drag exaggerates and makes heterosexual performances visible, but does not necessarily change the norms (Butler 1993, p.237). To act as a witch is a similar strategy that interrogates the notion of girlhood, but like a drag performance it is not necessarily subversive. Being a witch makes a girl different from other girls and a close female-female friendship makes the sexual constructions even more visible.

The feelings that Kim and Juliane have for each other are most explicitly expressed through their shared séances. Kim describes her desire for Juliane metaphorically as if in a dream, where the girls merge and become one another:

And then Ifelt it. The walls around us melted away
and the duskfound its way into the room, refreshing
and permeated with barely audible siren calls. It
filled me up. And suddenly I sensed something else;
for a split second Ifelt Juliane's presence in a new
way. Ican't explain it. If we really havesouls, itmay
have been our souls lightly touching each other. It
was a weird feeling, almost frightening. It almost
felt as if I were Juliane. To be another I.
(p.158, my emphasis)

Kim's experience is intense and intimate, almost suggesting a sexual act. Kim is struggling with her emotions when she tries to describe what is happening. She says 'I felt it' and 'I sensed something else', in the end she cannot articulate what she feels. In the scene quoted above, Kim feels the walls melting and dusk entering the room. She depicts it as hearing 'siren calls' which also supports the sexual experience by alluding to the nymph women in ancient Greek mythology. Sirens caused many sailors to lose their mind by the beautiful song that called for them. Kim, on the other hand, does not lose her mind. The Sirens may seduce sailors, but the dangerous aspects of their call change when a young girl is the listener. Kim becomes in fact more confident by the experience. After the merging, the girls cannot bring themselves to speak about their experience; it is so intangible and uncertain. Neither can the girls know for sure that they have shared the same experience, they can only tell each other that they felt something peculiar. They do not seem to be scared, but positively satisfied as they walk away from their séance out into the spring night

It was dusk now, not all dark. A wind played in my hair and the soft silk caressed my body. [...]

"Look!" said Juliane when we turned the corner.

"Look at the moon!"

And it was really beautiful; as if it was closer to earth than usual. It was round, white and shining 
like an enormous pearl, you could see all the mountains clearly. It was a moon to walk under in acemetery, a moon that shone over a ghost-town or was mirrored in a lake deep in the forest. Perhaps somewhere this happened.

(p.159)

Kim is physically present in this quote. The wind playing in her hair and the soft silk caressing her body links her bodily sensations to the surrounding nature in a sexualized manner. Through magical agency, Edelfeldt shows how desire is a crucial part of girlhood.

\section{Performing as a witch}

Realistically depicted witches spend a lot of time performing magic rituals. For the witch, words are highly important, especially the intention of words. There is a striking difference between Mazetti's and Edelfeldt's books in their depiction of magic which has further implications for the depiction of sexuality. Namely, the different manifestations of magic are connected to how the girls act out their sexuality. In Edelfeldt's novel the magic rituals that the girl protagonists Kim and Juliane take part in are described as something desirable, dark and selfish. Edelfeldt's novel expands these representations with generic gothic traits. Desire in the text formulates a specific discourse which takes its expressions from how the girls perform their rituals. Certain words, that they write before the ceremony, and darkness are used as strategies to gain power. Foucault discusses how desire is conceived in relation to power and points out the power of knowledge. Desire can thus be regarded as a form of acting, of having agency or of being deprived of agency (Foucault 1978, pp.89-90). Desire can be read as a way of stretching the edges of girlhood, creating agency of a different kind than 'normal' discursive constructions would allow (see similar discussions in McInally 2003, pp.1-3).

Within the context of Edelfeldt's book, being a witch means having power and exercising power over others as models for empowerment. Witchhood also implies a consciousness about power shifts and power repression. Yet, the witch-girls' power appears to be relative: they have power within their own private community of two, but are powerless outside it. ${ }^{2}$ Agency is therefore an ambivalent feature of the text.

In Mazetti's novel, being a witch means being able to perform positive actions including putting other people's interests before your own and acting unselfishly. It is possible to trace traits of Wiccan belief in the text, in terms of worshipping a Goddess and a God. In this context, the witch follows the wiccan rede, ${ }^{3}$ and the central aim of the text is to tell believers to act as one wishes to be acted upon, since bad deeds will haunt you. Acting unselfishly can be interpreted as making the witch potentially part of a traditional gender role-model for girls, but the wiccan tradition includes both women and men equally.

Fear of the inexplicable is apparent in one of the séances in Edelfeldt's novel. The séance ends abruptly in a manner that frightens the girls:

Juliane cried out. It was a short high scream. I pulled my hand from hers and opened my eyes. Juliane was staring in front of her. [...] "Somebody touched my shoulder!' Juliane was very pale. (p.85)

The ceremony is performed by the girls in order to contact the spirits and give their souls to the devil, but they are more fascinated by performing the ritual together than they are interested in making it work. Throughout the text the girls put a great deal of effort into finding the right dresses. They also buy 'magical rings' and listen to gloomy music (p.87). When the classmates show that they find the girls strange, Juliane and Kim decide to become even stranger; however, they do not dare to be that different. Afraid that their 'magical rings' might be mistaken for engagement rings, they don't wear them in school. The girls are meticulous in their preparation for the séances and it is their discussions of them that bind them, and not any meeting with the devil through a successful séance.

Whereas Kim and Juliane in Edelfeldt's book want to be witches and share a fascination for magic rituals, Linnea in Mazetti's novel is more reluctant to partake in such rituals, claiming she does not believe in witchcraft. However, Linnea is persuaded by her friend Malin to celebrate the Goddess Nerthus at the vernal equinox. The celebration 
goes wrong when the oil, with which the girls are supposed to light the fire, burns Malin's hands. Malin blames Linnea for not taking a genuine interest in the ritual:

\section{[...] I will stop that car but I don't want you to come with me to the hospital. You never wanted to be here ... and I think they felt it. Nerthus felt it!"}

Istared at her. Her voice was ice cold and croaking and sounded like it came from some other human being.

"Go away!" she shouted suddenly.

(p.82)

In this instance quoted above, Malin cuts Linnea off and does not want to discuss what has happened. The motif of girls' friendship in young adult novels often includes such a break from too intense relations. The break typically originates in a situation that the girls cannot deal with or discuss. In classical girls'fiction such as, Anne of Green Gables (1908), the friendship grows stronger through several conflicts. Contemporary Swedish authors of young adult novels repeat this theme, for example Cannie Möller in Tagg $i$ hjärtat (2000) [A thorn in the heart] and Katarina Kieri(2002)Ingen grekisk gud, precis [Not exactly a Greek god]. The cause of the conflicts vary, but usually the girls quarrel about a boy. In the books analyzed here the girls quarrel over who is the more giving party in the relationship, that is, who is more committed to the friendship. The girls themselves can initiate a time out in their friendship or someone else can force the break upon them as a punishment for them being too intimate. In this case, Malin and Linnea fall out because Malin is disappointed in Linnea, and Linnea has difficulty apologizing for her reluctance.

Edelfeldt's Juliane and I also features the interruption of a séance and a friendship. The ceremony is interrupted by Juliane's mother who walks in on the girls and discovers their 'playing'. These girls also perform witchhood by dressing up. Performativity is produced on the body, as Butler points out, and denotes a certain gender. (Butler 1999, p.173) Girls are supposed to be interested in clothes, and within the texts analyzed here they are. A different dress code is, however, introduced through the witch. In his dissertation, on the gothic in literature, film, music and roleplay, Mattias Fyhr discusses how the girls in
Edelfeldt's novel are interested in the gothic and take part in dark rituals. He analyzes the cover of the book where the girls are dressed up as witches and in the background the full moon and an old castle predict and signify the gothic influences. They place themselves within the 'gothic side', thus having agency through the dark rituals they perform (Fyhr 2003, pp.157-159). The girls are fascinated by the gothic and act through it, constructing a different kind of girlhood as witches.

When Juliane's mother walks in on the girls' séance, she interrupts their act of dressing up as witches. Kim, whose narrative perspective the readers share, seems to be ashamed and aware of how naïve their ritual might seem from an outsider's perspective. Juliane, on the other hand, is angry because she finds Kim's attitude patronizing. When she cannot convince Kim to stay the night, Juliane feels rejected and so their friendship is put on hold:

\begin{abstract}
Juliane stared at me. "Idiot", she said. "Go home, to your mum and dad and to happiness. You can learn how to knit and bake and start to hang out with Yvonne again, 'cause I sure don't want to be your friend anymore. You can go to hell. [...]
\end{abstract}

$$
\text { (p.116) }
$$

Usually the break in friendship means that when the crisis is resolved the friendship is renewed, with even stronger bonds. Having resolved a major conflict, Kim and Juliane have gained deeper knowledge about each other and learn that even though they may have disagreements they can still trust each other. Relationships are important to the realistically depicted girls, as it is through their close female friendship, that they mature and construct their understanding of themselves. When the girls perform as witches and/or when they partake in close female friendship heteronormative models are not subverted. But the figure of the witch proposes a strategy for interrogating heteronormativity. The girls are able to have agency as witches within their own private community. The interrogation visualizes the normativity and witchhood also stretches the borders for girlhood in general by questioning the norms. 


\section{Fantastic parental guiding}

Whereas realistically depicted witches rely on networking between girl characters, fantasy witches depend on an internalized heteronormativity. According to Margery Hourihan, relationships within fantasy literature are based on hierarchical structures and reflect the basic dualism of superiority/subordination that is inscribed in the structure of the hero tale (Hourihan 1997, p.77). Witch girls in fantasy are typically described as undergoing a lonely inner quest towards maturity. They are constructed as female heroes, superior to other characters and placed in a heroic context. Due to the female hero's more openly gendered position female-female friendships tend to become subordinated to her quest. The girl-witch character is constructed differently in fantastic and realistic settings. Butler develops Julia Kristeva's discussion of exclusion/abjection and argues that it is not enough to claim that human subjects are constructed. Instead, one must acknowledge that human subjects are always produced in relation to what is considered 'less “human”, inhuman, humanly unthinkable' (Butler 1993, p.8). The hierarchical structure of fantasy allows only a specific kind of character. In other words, fantasy characters are rendered intelligible according to how subjects are positioned as 'humanly thinkable'.

The hero's maturation in fantasy is often symbolically depicted as the protagonist's struggle to come to terms with her magical gifts. In Kaaberbøl's The Shamer's Daughter (2000/2005) tetralogy, the girl protagonist Dina's magical gifts paradoxically become a vehicle both for deconstructing the male hero as a norm and for depicting normative values of sexuality. According to Mikhail Bakhtin, an individual's subjectivity is formed through an interaction between various ideological discourses and voices (Bakhtin 1981, p.346). There is, in other words, an analogy between the formation of subjectivity and the dialogic structure of language. Kaaberbøl's protagonist, Dina, holds a variety of subject positions that enable the narrator to deconstruct Dina's heroic position as a unified subject. On the other hand, Dina's relationships reveal that she is a traditional heteronormativite hero.

Heteronormativity within the Shamer's chronicles makes visible the relation between parents and child. In comparison with the previously analyzed realistic narratives, Kaaberbøl's fantasy narrative describes the relation between child and adult as hierarchical. The motif of sexuality is thus made invisible since a graphic description of sexuality would be explicitly incestuous. The girl protagonist depends on her mother, but the mother-daughter relationship is also based on a more mutual bonding between them. Dina's skills take the form of witchcraft, which she has inherited from her mother:

\begin{abstract}
"What you have is a gift," she said. "And a power, not to be abused." She reached into her apron pocket and held something out to me. "Here". [...] It was a pendant. [...] Starting tomorrow I shall begin to teach you how to use your gift - and how and when not to use it."
\end{abstract}

(The Shamer's Daughter, pp. 11-12)

Dina has shamer's eyes - eyes with the power to make people feel ashamed of all the bad or immoral things they have done. She becomes her mother's apprentice in order to learn to control the gift. The cultural historian, Diane Purkiss, argues that the archetypal image of the witch as linked to matriarchy and mother-daughter learning is nothing but a myth and that, as a story that builds on a clear distinction between good and evil, the witch's narrative is only another variant of the hero tale (Purkiss 1996, pp.7-8). Like the male hero, the female witch protagonist's identity is constructed as stable, coherent and unique. However, Dina's construction as a witch is far more complex than Purkiss suggests. As the title of the third book, The Serpent Gift (2001/2005), indicates, Dina has another magical gift. This gift is inherited from her father and is highly ambiguous in nature. When playing on a flute that belongs to her father, Dina is able to create dreams and illusions, a different kind of truth: 'I had the serpent gift, I could make other people's eyes and ears lie to them. Lie, or dream. Or maybe both' ( p.91).

The serpent gift is the antithesis of the shamer's gift: moral is pitted against immoral, truth against falsehood. However, what first appears to be a binary concept of 'male' and 'female' powers gradually transforms into a dialogue between different forces. The dialogue then functions as a strategy for interrogating the relation between two 
opposite poles: Dina's father's serpent gift and mother's shamer's eyes.

Dina is both empowered and disempowered by her magical gifts: a paradox which corresponds to Michael Foucault's 'domination-repression' model, which is a scheme that underlines the dialogic nature of power. According to Foucault, repression is considered in relation to domination, thus creating a 'perpetual relationship of force' (Foucault 1980, p.92). Witchhood is not an alternative or means of escape for the fantasy girl, as it is for the realistically depicted girl. Instead, the witch girl in fantasy literature has to confront her magical skills. The shamer's gift has a mind of its own and Dina cannot always control the forces of her gift. Instead the gift controls her, thereby disempowering her. Her witchcraft also raises issues of whether power is morally 'good'or 'evil', and of responsibility. When her friends turn on her and cruelly bully her, she uses her gift to take revenge:

\section{"Look at me, you vain little peahen. Look into my eyes!"}

She didn't want to. She screamed and wept, trying to close her eyes, but I had her, and I had no intention of letting her go. "Look at me!" I hissed once more, and she seemed to lose the will to resist me. The periwinkle blue eyes slid open and stared into mine."

(The Shamer's Signet, p. 8)

This episode prompts a lecture about moral behavior for Dina and she is told by her mother not to misuse her powers. Thus, it is possible to see that although the female hero is allowed to explore the darker side of her psyche, she is always guided back to the morally acceptable - which is effectively controlled by the narrative.

Not only does Dina herself act immorally, her powers can also be abused. At one point Dina has to use her gift to make others feel ashamed and, consequently, she loses her gift. Her powers are abused against her will in a scene that suggest rape: 'He would do it again. He would use me as a weapon, over and over again. And if I refused, Tavis would pay the price. [...]' (The Shamer's Signet, p.148)
The 'rape' is repetitive. The man who abuses Dina wants her to control his workers and if she refuses, he threatens to hurt a young boy who is very close to her. Dina feels she has no way of denying him what he wants. But if she oversteps her moral boundaries, her powers will disappear. Dina's witchcraft is in this way restricted by values relating to the construction of the hero, and especially of the female hero, as morally superior. Her shamer's gift seems to empower her, but when she no longer can control it her agency as a girl is circumscribed. Agency presupposes that girl protagonists recognize themselves as the agents of an action, thereby claiming a subject position (Trites, 1997, 28). Constructed as an object, Dina cannot claim agency in the narrative and consequently loses her empowered subject position.

Foucault stresses that power only 'exists in action' (Foucault 1980, p.89), and Dina not being able to actively choose or control her witchcraft effectively circumscribes the powers she has inherited from her mother. The narrative suggests that it is Dina who accepts the serpent gift. Still, her mother, who fears and despises her father's skill, tells Dina that 'if he can, he will awaken it [the gift] within you' (my emphasis, The Serpent Gift, p.208). According to this assertion, what appears to be Dina's choice is not hers after all. She is stripped of her power to act and subordinated to her father's will. The relationship between father and daughter takes incestuous forms. In one scene, Dina is forced to undress in front of her father. In another scene she has a dream about snakes:

\section{Something touched myleg. I looked down and saw that a snake had wound itself around my ankle and was slithering up my leg. I screamed and kicked and tried to get it off me, but suddenly there were snakes everywhere; one fell down from the ceiling and wrapped its scalylength around myneck; there were snakes on my arms, on my legs, and when I opened my mouth to scream I found I couldn't, because something was coming out of me, there was a snake inside me'}

(The Serpent Gift, p.239)

The dream is associated with her father, who is the keeper of the serpent gift. In this scene, Dina is deprived of agency and symbolically dominated by her father. The importance 
of Dina's dream is emphasized by the significant role that dreams play in the narrative. Dina is not sexually abused by her father, but the symbolism of the dream suggests that she is. The snake as the immoral animal that leads the girl from the right path is a very distinctive sign of how Eve, or Dina in this case, is lead from the path of virtue and introduced to dangerous new knowledge of sexuality.

Gradually Dina begins to explore her serpent gift, and she comes to accept the gift when she realizes that she can use it to do good. In the final battle between good and evil, Dina uses her father's flute to create a dream. Here again, Dina's agency is subordinated to the power of her father's flute. However, after she has played the flute, she puts it away:

Ilowered the flute. With a stab of sadness I suddenly knew that I would never play it again. Other flutes, perhaps, but not this one. It could do too many things. It knew too much. Sometimes Ifelt the flute was playing me, and not the other way around.

(The Shamer's War, pp.339-340)

Dina chooses not to use her father's flute anymore. Thereby, she rejects her father's powers and reclaims agency. She is no longer 'played' by her father. As a result, she does not have to choose between her mother's and her father's inheritance. No longer abused, she retrieves her witchcraft. She can now claim the gifts for herself, and is thus seen to be able to define her own subject positions between the opposite poles.

\section{The lonely he(te)ro}

Characters in fantasy literature that are of less significance than the hero are often denied subjectivity. According to Trites, female companion characters serve to strengthen the female protagonist's subject position by providing her with relationships in which her voice is heard (Trites, 1997, p.80-99). While this is true within the realistically depicted female friendships investigated here, the fantastic setting does not allow equally close relations between girls.

Hourihan's discussion of the heroic quest points to the important power disparity between the hero and his companion (Hourihan 1997, p.77-79). Dina subverts this heroic trope in her dependence on relationships. When
Dina helps a girl called Rose, who is abused by her older brother, she finds a friend and companion. In fantasy literature, the companion often represents a marginalized group, which further strengthens the hierarchical structure of the relationship. The friend is disempowered from the very beginning (Hourihan 1997, p.79). Due to her family situation, Rose feels inferior to Dina. She thinks that Dina looks down on her because her mother is not married and because her brother hits her, and that is why Dina won't look her in the eyes. Dina, in turn, is scared that Rose will reject her friendship if she realizes that Dina is a shamer. Dina expects Rose to turn away, but Rose is brave and honest enough to meet Dina's gaze. In a crucial episode Dina relieves Rose of her shame:

"Oh yes, she was ashamed. Her shame was deep,
sincere, and terrible. But she had no reason to
be! I don't know exactly how I did it. It was the
opposite of making people ashamed of themselves,
and yet it was the same thing. I let her see herself.
I made her see the brave, stubborn, honest Rose,
I had seen. [...] She was stubborn. She fought
me. But I succeeded in the end: I took her shame
away from her.

(The Shamer's Daughter, pp.175-176)

Dina uses her eyes to make Rose 'see herself' and is finally able to take '[Rose's] shame away from her'. Dina's skill to cause and erase shame places her in a powerful position in relation to Rose. While Rose is depicted as Dina's true friend, in fact she becomes the female hero's companion. When Rose bravely stabs an enemy, she becomes an outlaw like Dina. She cannot return home and is forced to join Dina on her quest. Although Rose seems pleased to join Dina, she is, in fact, deprived of her freedom. It is possible to read this narrative feature as just another example of the need to negate female power by positioning it at the margins. Conversely, displaced power can become an alternative source of strength for the female hero. In the latter case, the depiction of Rose can be viewed as a strategy to deconstruct an heroic characterization. Both fantastic and realistic friendships thus serve as strategic positions for the girls. However, Dina's and Rose's relationship does not correspond to the more sexualized girl - girl relations in the realistic novels. 
Fantasy literature usually depicts a traditional heterosexual understanding of the girl witch, whereas realistic fiction dealing with girl witches tends to express a subversive understanding of the witch girl's sexuality. This is rather surprising, since fantasy literature in general is usually seen to be the genre with a greater potential for subversion. That is at least what Roderick McGillis argues when he discusses the potential of fantasy to allow 'us to see the world again as if for the first time' (McGillis 1996, p.72). ${ }^{4}$ John Stephens also points out how children's literature criticism often seems to have 'the urge to polarize fantasy and realism into rival genres' (Stephens 1992, p.241). The assumption is that realism represents some sort of 'truth', whereas fantasy represents 'new truth' as different ways of interpreting the world. But, as we have shown in this article, it is within the realistic and not the fantastic narratives that subversive undertones of girls' sexuality are hinted at. Within the fantastic setting, the depiction of sexuality follows the norms of heterosexuality.

Contemporary fantasy usually depicts the protagonist's sexuality very cautiously and the hero's sexual awakening is often described symbolically in dreams or in intertextual references. Hourihan even points out that 'most later hero stories $[\ldots]$ are conspicuously asexual at the overt level' (Hourihan 1997, p.78). Realistically depicted witch girls share the symbolical awakening with the fantasy witches. The magical rituals enable the girls to mature and form their own understanding of themselves as active sexual subjects. Since heterosexuality is the norm sexuality is often not an issue at all in fantasy. Sexual relations in general are subordinate to the hero's quest. Therefore, relationships are typically heterosexual and do not question the norm. Whereas the friendship between witch girls in realistically depicted fiction is so intimate that it may suggest lesbianism, the friendship between girls in fantasy literature seldom has any sexual undertones. Dina and Rose share a certain intimacy in that Dina is able to see Rose's thoughts and memories when she looks into her eyes. Their relationship can in this sense be described in terms of interdependency. While dependency implies a hierarchical model, interdependency builds on an equal relationship involving mutual dependency (cf. Trites 1997, p.83). Dina becomes close friends with Rose because Rose dares to look Dina in the eyes:

Iwaited. Here it was. In a minute, her glance would begin to waver, and she would turn her back on me. She might even call my mother a witch, and me a devil's brat. Enough people had.

She didn't turn away.

She still didn't turn away.

And then pictures started to float between us [....].

(The Shamer's Daughter p.175)

Rose accepts Dina and her special gift. When she submits to the gaze, she makes a conscious decision to let Dina into her life. The characterization in Kaaberbøl's series is far more complex and ambiguous than in the hero tale, and the power structures between Dina and Rose are not as obvious as in the hero's relations. Both Dina and Rose find strength in their relationship:

"Look at me", she [Rose] said, a bit more loudly. "Look at me. Until I know that I dare." Sometimes there are things that simply can't be put into words. Things inside you, I mean. That's how I feel right then. I didn't say anything because I couldn't. But I looked my friend straight in the eyes until she could feel that I knew she was a strong and brave girl who dared to do practically anything.

(The Shamer's Daughter, p.211)

Rose is empowered by her companionship with Dina. Still, their friendship is not completely equal. Dina is the one with the power to create and withdraw shame. And when not on a quest together, Rose is depicted as a servant who helps around the house.

In the Shamer's chronicles, intimacy is only allowed in terms of heterosexuality. Dina's sexual awakening is subtly described in terms of love for the only boy who is able to look her in the eyes. Despite hints that they will become lovers, this is not made explicit in the text. Dina's relationship with this boy is possible because it fits within the norms of heterosexuality. As in her relationship with Rose, Dina is the one in power. She is the female hero and he is the subordinate party. This re-establishment of 
heroic values concerning friendship and sexuality reveals Dina's function in the text to be male rather than female and negates her powers as a female character.

\section{Conclusion}

In this article, we have discussed how girl characters perform witchhood within realistic and fantastic settings. The difference between the realistically and the fantastically depicted witch figure offers insight into the normative status of heterosexuality. Whereas some might expect that the realistic depictions would describe heteronormativity and that fantastic narratives would subvert heteronormativity, fantastic literature relies on a hierarchical structure, in which interaction with others is as a way for the hero to mature. In the books analyzed here, realistically depicted girl witches call normativity into question when they reveal alternative sexual preferences. The girls do not act on their feelings, but their intimate relationships suggest potential lesbianism. Fantasy witches who attain a heroic status do subvert subject positions for girls, but heterosexuality is seldom questioned and the hero has to come to terms with her powers on her own.

As these stories show, representations of witches are far more differentiated than Stephens' narrow categories suggest. Dina is not a stunning fantasy beauty of the sorceress-witch kind. The realistic witches do not conform to the crone-witch or the wise-witch categories either, since none of them are experienced enough to be wise or evil. The teenage witches explored here offer interesting examples of girl strategies in relation to power and heterosexuality. Making magic happen, is always first and foremost about making themselves visible and finding their own way in society.

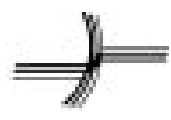

\section{NOTES}

1. Translations of the texts have been provided by one of the authors since neither Edelfeldt's nor Mazetti's books is translated into English. Katarina Mazetti's It is Over Between Red Riding Hood and the Wolf is the second book in a trilogy whose first title, God and I Broke Up (2005), is translated into English.

2. The notion of community within this context functions as a strategy for developing agency, and is connected to the concept of female community (cf. Nina Auerbach).

3. Mazetti's novel ends with a paratextual note which says Malin has read a Danish handbook for witches; however, the note also explains that Malin does not remember correctly or has misunderstood the handbook. It is therefore suggested that readers check before practising any of the rites depicted in the book.

4. See also Rosemary Jackson (1981) and Ann Swinfen (1984).

\section{REFERENCES}

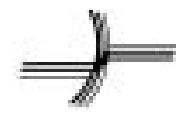

Auerbach, Nina (1978) Communities of Women: An Idea of Fiction. Cambridge Mass., Harvard University Press.

Bakhtin, Mikhail (1981) The Dialogic Imagination. Four essays. Michael Holquist (ed), Translated by Caryl Emerson \& Michael Holquist. Austin, University of Texas Press.

Butler, Judith (1990) Gender Trouble. Feminism and the Subversion of Identity. New York, Routledge.

Butler, Judith (1993) Bodies that Matter. On the Discursive Limits of 'Sex'. New York, Routledge.

Edelfeldt, Inger (1982) Juliane och jag [Juliane and I]. Stockholm, AWE/Gebers.

Foucault, Michel [1978](1990,) The History of Sexuality: An introduction, volume I. Translated by Robert Hurley. New York, Vintage.

Foucault, Michel (1980) "Lecture One: 7 January 1976", in Power/Knowledge: Selected interviews and other writings 1972-1977. Colin Gordon (ed). New York, Pantheon. pp.78-92. 
Fyhr, Mattias (2003), De mörka labyrinterna: Gotiken i litteratur, film, musik och rollspel, [The Dark Labyrinths: The Gothic in Literature, Film, Music and Roleplaying Games.] (Diss, Stockholm). Lund, Ellerströms.

Hourihan, Margery (1997) Deconstructing the Hero: Literary Theory and Children's Literature. London, Routledge.

Jackson, Rosemary (1981) Fantasy: The Literature of Subversion. London, Routledge.

Kaaberbøl, Lene [2000] (2005) The Shamer's Daughter. London, Hodder Children's Books.

Kaaberbøl, Lene [2001] (2005) The Shamer's Signet. London, Hodder Children's Books.

Kaaberbøl, Lene [2001] (2005) The Serpent Gift. London, Hodder Children's Books.

Kaaberbøl, Lene [2003] (2005) The Shamer's War. London, Hodder Children's Books.

Kieri, Katarina (2002) Ingen grekisk gud, precis. Stockholm, Rabén\&Sjögren.

Mazetti, Katarina (1998) Det är slut mellan Rödluvan och vargen. Stockholm, Alfabeta.

McGillis, Roderick (1996) The Nimble Reader. Literary Theory and Children's Literature. New York, Twayne.

McInally, Kate (2003) 'Camphor Laurel: A revision of desire', Papers: Explorations into Children's Literature 13, 2: 27-36.

Montgomery, L. M. [1908] (1994) Anne of Green Gables. Heartfordshire, Wordsworth Edtions Ltd.

Möller, Cannie (2000) Tagg i hjärtat. Stockholm, Bonnier Carlsen.

Nikolajeva, Maria (2002) The Rhetoric of Character in Children's Literature. Lanham, Scarecrow Press.
Purkiss, Diana (1997) The Witch in History. Early Modern and Twentieth-century Representations. London, Routledge.

Stephens, John (1992) Language and Ideology in Children's Fiction. New York, Longman.

Stephens, John (2003) 'Witch-Figures in recent children's fiction: The subaltern and the subversive', in. Lawson Lucas, Ann (ed.) The Presence of the Past in Children's Literature. Westport, Praeger, pp.195-202.

Swinfen, Ann (1984) In Defence of Fantasy. A Study of the Genre in English and American Literature since 1945. London, Routledge.

Trites, Roberta Seelinger (1997) Waking Sleeping Beauty. Feminist Voices in Children's Literature. Iowa city, Univ. of Iowa press.

Trites, Roberta Seelinger (1999) "“Queer Performances": Lesbian Politics in Little Women' in Alberghene, J., \& Lyon Clark, B. (eds.) Little Women and the Feminist Imagination: Criticism, Controversy, Personal Essays. New York, Garland.

Trites, Roberta Seelinger (2000) Disturbing the Universe. Power and Repression in Adolescent Literature. Iowa city, Univ. of Iowa press.

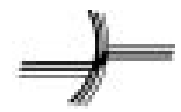

\section{BIOGRAPHICAL NOTE}

Mia Franck is currently Assistant at Comparative Literature, Åbo Akademi University in Finland. She is writing her doctoral thesis about girls' sexuality in Swedish young adult novels.

Rebecka Fokin-Holmberg is a doctoral student at Comparative Literature, Åbo Akademi University in Finland. Her doctoral thesis is on empowered girls in fantasy fiction. 